\title{
Nükleer Santraller Hakkında Fen Bilgisi Öğretmenlerinin Görüşü: Akkuyu Örneği
}

\section{Science Teachers' Views on Nuclear Power Plants: Akkuyu Sample}

\begin{tabular}{|c|c|}
\hline & Süleyman Tolga TEKGÖZ ${ }^{1}$, Feride ERCAN YALMAN ${ }^{2}$ \\
\hline $\begin{array}{l}\text { Anahtar Kelimeler } \\
\text { Sosyobilimsel konu, } \\
\text { Nükleer enerji, } \\
\text { Nükleer santraller, } \\
\text { Fen bilimleri öğretmeni. }\end{array}$ & 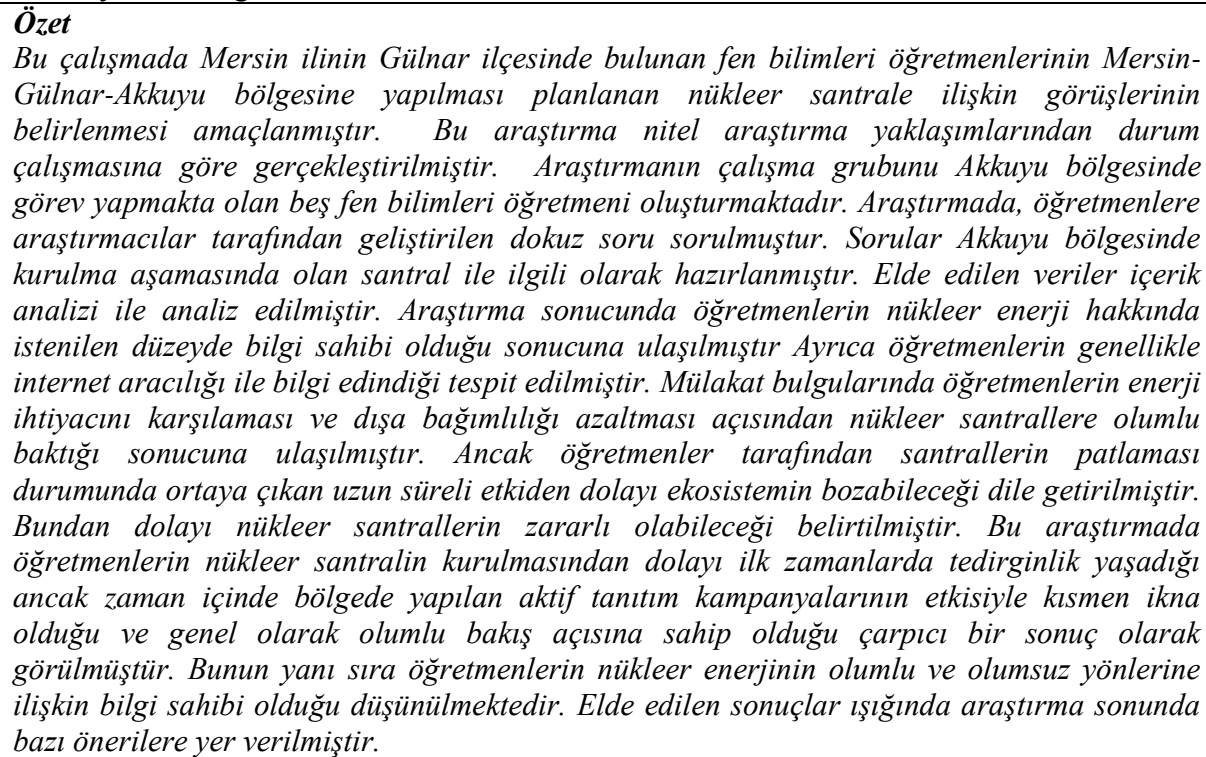 \\
\hline $\begin{array}{l}\text { Key Word } \\
\text { Socioscientific issue, } \\
\text { Nuclear energy, } \\
\text { Nuclear power plants, } \\
\text { Science teacher. }\end{array}$ & $\begin{array}{l}\text { Abstract } \\
\text { This study aimed to determine the views of the science teachers in the Gülnar district of } \\
\text { Mersin province regarding the nuclear power plant planned to be constructed in Mersin- } \\
\text { Gülnar-Akkuyu region. Case study, one of the qualitative research approaches, was used in } \\
\text { this research. The study group consisted of five science teachers employed in the Akkuyu } \\
\text { region who were asked nine questions developed by the researchers in regards to the power } \\
\text { plant which is in the phase of establishment in the Akkuyu region. The data obtained were } \\
\text { analyzed by content analysis. Based on the results, it was concluded that the participating } \\
\text { teachers had the required level of knowledge about nuclear energy. In addition, it was } \\
\text { determined that the teachers generally obtained information via the internet. The interview } \\
\text { findings showed that the teachers were open to the idea of nuclear power plants and thought } \\
\text { nuclear power plants met energy needs and reduced dependency on foreign countries. } \\
\text { However, the participants stated that nuclear power plants may be harmful due to long-term } \\
\text { effects in case of accidents in power plants and they were concerned about the disruption of } \\
\text { the ecosystem. This study presented a striking result that at first, the participants were } \\
\text { concerned about the construction of the nuclear power plant, but were partially convinced } \\
\text { over time by the active promotion campaigns in the region and in general had a positive } \\
\text { outlook to nuclear power plants. In addition, it is established that teachers have knowledge } \\
\text { about the positive and negative aspects of nuclear energy. The study offers some suggestions } \\
\text { in the light of the obtained results. }\end{array}$ \\
\hline
\end{tabular}

Atıf için: Tekgöz, T., \& Ercan-Yalman, F. (2020). Nükleer santraller hakkında fen bilgisi For Citation öğretmenlerinin görüşü: Akkuyu örneği. Muğla Sitkı Koçman Üniversitesi Eğitim Fakültesi [MSKU Journal of Education], 7(2), 144-158. DOI: 10.21666/muefd.706847

Received: 20.03.2020 Accepted: 11.10.2020 Published: 01.11.2020

\footnotetext{
${ }^{1}$ Mersin Üniversitesi, Eğitim Bilimleri Enstitüsü, s.tolga333@gmail.com ORCID: 0000-0001-6444-7926

${ }^{2}$ Mersin Üniversitesi Eğitim Fakültesi, feride@mersin.edu.tr ORCID: 0000-0003-1037-1473
} 
Bilimsel ve teknolojik gelişmelerin etkisi ile değişen yaşam şartları yeni durumları da beraberinde getirmektedir (Herawati ve Ardianto, 2017). Bir diğer ifade ile günümüzde teknoloji, sosyal yapı ve bilim birbirinden ayrı olamamakta ve yapılan bilimsel çalışmalar toplumu etkilemektedir. Bu sebeple toplumların bilimsel çalışmalardan ve gelişmelerden ayrı tutulmaması gerektiği düşünülmektedir (Sürmeli, Duru ve Duru, 2017). Bir ayağı bilimsel, bir ayağı teknolojik ve bir ayağı sosyal olan bu konular zaman zaman bireyleri ve toplumları ikileme de sürükleyebilmektedir (Ateş ve Saraçoğlu, 2013; Evren Yapıcıoğlu, 2016). Alanyazında sosyobilimsel konular olarak adlandırılan ve ikilemleri barındıran bu konuların bazıları nükleer enerji, genetiği değiştirilmiş organizmalar, küresel iklim değişikliği, pandemik aşılar vb. şeklinde sıralanabilir (Eş, Mercan ve Ayas, 2016; Zeidler, Walker, Ackett ve Simmons, 2002). Bahsedilen bu konular bireyi, toplumu ve çevreyi ilgilendiren yarar ve zarar ekseninde çözülmeyi bekleyen konulardır (Ateş, 2013; Özdemir, 2014; Ratcliffe ve Grace, 2003). Bu bağlamda sosyobilimsel konuların doğası gereği karmaşık, kesin bir cevabı olmayan, çoğunlukla tartışmalı ve hatta riskleri, ihtimalleri barındıran konular olduğu söylenebilir (Topçu, 2015). Örneğin Kolsto ( 2001) ve Sadler ve Zeidler'e (2005) göre, "Hastalıklara karş1 geliştirilen aşıların uygulanması, GDO'lu besinlerin tüketimi, klonlama ve nükleer santraller gibi pek çok konu sadece bilim insanlarının, karar verebileceği durumlar olmaktan çıkmış toplumların ve devletlerin insiyatifindeki konulardır". Tartışmalarda son noktanın konulamadığı bu konular, farklı görüş ve yorumları da beraberinde getirmektedir (Atabey, 2016; Kolsto, 2001; Nielsen, 2012; Sadler ve Zeidler, 2005; Topçu, 2015). Söz konusu tartışmalı konular fen öğretim programında da yerini almakta ve fen okuryazarı olma kavramı ile de sıklıkla bir arada kullanılmaktadır. Çünkü son birkaç öğretim programında hem sosyobilimsel konulara yer verilmekte hem de fen okuryazarı bireyler yetiştirme üzerine odaklanılmaktadır (Seçkin Karaca, 2018). Fen okuryazarlığı ile toplumu oluşturan bireylerin fen ile ilgili öğrendiklerini günlük hayatla ilişkilendirmeleri beklenmektedir (Demircioğlu ve Uçar, 2014). Fen okuryazarı olabilmek ve bunu geliştirmek için birçok araştırmacı tarafından öğrenenlerin sosyobilimsel konulardaki karar verme ve yorum yapma yeteneğinin öneminden bahsedilmektedir (Kinslow, Sadler ve Nguyen, 2019; Kolsto, 2006; Okada, 2008; Sadler ve Donnelly, 2006; Sadler ve Zeidler, 2005; Wu ve Tsai, 2011; Zohar ve Nemet, 2002). Bu eksende bireylerin muhakeme güçlerinin gelişmesi açısından sosyobilimsel konuların öğretiminin önemli bir yeri olduğu düşünülmektedir (Dawson ve Carson, 2017; Driver, Newton ve Osborne, 2000; Özdemir, 2014; Topçu, 2015; Zeidler ve Nichols, 2009). Bir diğer ifade ile sosyobilimsel konuların öğretim programında ismen tanıtılmasının çok daha ötesinde ele alınması gerektiği ve argümantasyon ve muhakeme eşliğinde irdelenmesi gerektiği düşünülmektedir (Saunders ve Rennie, 2013). Bu bağlamda öğretim programında yer alan ilgili konu ve kazanımların amacına ulaşabilmesi için öncelikle öğretmenlerin sosyobilimsel konulardaki bilgi ve görüşleri önem arz etmektedir (Borgerding ve Dă̆ıstan, 2018; Pitiporntapin, Yutakom ve Sadler, 2016; Saunders ve Rennie, 2013).

Ülkemiz gündeminde olan ve fen öğretim programında da yer alan sosyobilimsel konulardan bir tanesi nükleer enerjidir. Yaşanan hızlı nüfus artışının yanında teknolojide gerçekleşen büyüme enerji ihtiyacında bir açık oluşturmuş bunu gidermek adına nükleer enerji dünya çapında kendinden sıkça bahsettirmeye başlamıştır (Jho, Yoon ve Kim, 2013). 1970'li yıllarda enerji üretiminde yaşanan kaynak sorunları ülkelerin nükleer enerjiye ilgisini arttırmaktadır. Bu sorunun ileriki zamanlarda daha büyük olumsuzluk oluşturmaması adına nükleer enerji kullanımı olumlu bir çözüm yolu olarak görülmektedir (Jewell ve Ateş, 2015; Temurçin ve Aliağaoğlu, 2003; Udum, 2010). Bazı kesimler nükleer santrallerin faydalı olduğunu ve enerji açısından dışa bağımlı olmaktan kurtarabildiğini düşünmektedir. $\mathrm{Bu}$ sebeple nükleer santrallerin açılması bazı kesimler tarafından desteklenmektedir. Buna karşın diğer bir kesim ise insan hayatının her şeyden üstün olduğunu ve çevreye verilecek zararın çok fazla olduğunu düşünmektedir. Bu sebeple nükleer santral kurulumuna karşı muhalif bir kesim de yer almaktadır. Çünkü nükleer santrallerde, patlama meydana geldiğinde bir atom bombası etkisi yaratabilmekte ve etkileri yıllarca kuşaktan kuşağa hissedilmektedir. Çernobil faciası yakın tarihin en önemli örneği olarak gösterilmektedir (Yıldırım ve Örnek, 2007). Aynı şekilde Akkuyu'da bir kaza olması durumunda sadece o bölgede yaşayanların etkilenmeyeceği ileri sürülmektedir. Fukuşima'da olduğu gibi denize olan sızıntı nedeniyle tüm Akdeniz tehlike altında kalabilecektir. Bununla birlikte Çernobil'de olduğu gibi havaya olan sızıntılar nedeniyle rüzgârın yönüne, yağmur yağmasına göre Türkiye'nin çeşitli bölgelerinin veya başka ülkelerin de etkilenebileceği ön görülmektedir (Yapıc1, 2015). Nükleer santrallerin yarar ve zarar kısmı biraz daha açıldığında nükleer santrallerin daha çok enerjiye ve daha az karbon salınımına zemin hazırladığı söylenebilir (Jho, Yoon 
ve Kim, 2013; Kubota, 2012). Buna karşın sürekli sızıntı oluşması ile birlikte radyoaktif atıkların imhası ve depolanmasından dolayı dezavantajlarından bahsedilebilir. Bununla birlikte başta deniz ekosistemi olmakla birlikte birçok canlı türünün etkilenmesi de söz konusudur. Bu nedenle konu yıllardır tartışmaya açık durumdadır (Lee ve Yang, 2013). Gerek bilim insanları gerekse halk için bu tartışmalı durum devam etse de ülkemizde Akkuyu bölgesindeki nükleer santralin yapımına başlanmıştır (Aydın, 2020). Yapılan resmi açıklamalarda enerji ihtiyacının olduğu ve Türkiye'nin ilerleyen yıllarda enerji ihtiyacını karşılamak için nükleer santrallerin arttırılması ile ülkemizdeki enerji sorunun kısmen çözülebileceği belirtilmektedir (Furuncu, 2016). Bu bağlamda nükleer santrallerin ülkenin enerji ihtiyacının en az \%10'unu karşılaması ve söz konusu santrallerin öncelikle Akkuyu ve Sinop'ta faaliyete geçmesi planlanmaktadır (Enerji ve Tabi Kaynaklar Bakanlığı, 2014; Sürmeli, Duru ve Duru, 2017 ).

Alanyazına bakıldığında nükleer santraller ile ilgili birçok çalışma yer almaktadır (Ateş ve Saraçoğlu, 2013; Ayaz, Karakaş ve Sarıkaya, 2016; Aydın, 2020; Borgerding ve Dağıstan, 2018; Demircioğlu ve Uçar, 2014; Eş, Mercan ve Ayas, 2016; Furuncu, 2016; Kapıcı ve İlhan, 2016; Kılınç, Boyes ve Stanisstreet, 2012; Özdemir, 2014; Palabıyık, Yavaş ve Aydın, 2010a; Sürmeli, Duru ve Duru, 2017; Yener, Aksüt, Somuncu Demir, 2017; Yılmaz, 2015). Yapılan çalışmalar incelendiğinde, çoğunlukla fen bilimleri ve sosyal bilimler alanında çalışmalar yapıldığı görülmektedir. Örneğin Aydın (2020) tarafından yapılan çalışmada nükleer enerji konusundaki politikalar ele alınırken Yılmaz (2015) tarafindan yapılan çalışmada santrallerin güvenlik ve ekonomik boyutu, Furuncu (2016) tarafından yapılan çalışmada ise enerji bağımlılığı üzerinden nükleer santraller ele alınmaktadır. Sevim ve Ayvacı (2020) nükleer santrallerin sosyal kabul edilebilirliğinin çok araştırılmadığına vurgu yaparak bu konunun genel olarak çevre teması altında ele alındığının belirtmektedir. Bu noktadan hareketle eğitim alanında ise sınırlı sayıda çalışmanın varlığına işaret edilmektedir. Nükleer santralleri merkeze alan çalışmaların (Ateş ve Saraçoğlu 2013; Demircioğlu ve Uçar 2014; Dikmenli, Öztürk Demirbaş ve Gafa, 2019; Eş, Mercan ve Ayas, 2016; Saraç ve Bedir, 2014; Sevim ve Ayvac1, 2020; Sürmeli, Duru ve Duru 2017; Zengin, Keçeci ve Kırılmazkaya, 2012) ise genellikle öğretmen adayları ve öğrencilerle yapılmış olduğu ve veri toplama aracı olarak genellikle ölçek ve anketlerin kullanıldığı görülmektedir. Örneğin Kapıcı ve İlhan (2016), Özdemir (2014), Sürmeli ve diğerleri (2017) tarafindan yapılan çalışmalarda ögretmen adaylarının nükleer enerjiye yönelik görüş ve tutumları farklı değişkenler açısından incelenmektedir. Bahsedilen çalışmalarda katılımcıların büyük çoğunluğunun nükleer santraller konusunda olumsuz tutuma sahip olduğu dile getirilmektedir. Ateş ve Saraçoğlu'nun (2013) araştırma sonucunda gençlerin büyük çoğunluğunun nükleer santraller konusunda kayg1 ve olumsuzluk içerisinde olduğu rapor edilmektedir. Ayaz ve diğerleri (2016) tarafindan yapılan çalışmada ise nükleer enerji konusundaki kavram yanılgısına vurgu yapılmaktadır. Benzer sonuçlara Eş ve diğerleri (2016) tarafindan yapılan çalışmada da ulaşılmaktadır. Bu çalışmalara ilave olarak Özdemir ve Çobanoğlu (2008) tarafından yapılan çalışmada öğretmen adaylarının nükleer enerji konusundaki sınırlı bilgiye sahip olduğu ifade edilmektedir. Yukarıda bahsedilen alanyazın sonuçlarından yola çıkarak çalışmalarda genellikle öğretmen adaylarının ve öğrencilerin yer aldığını söylemek mümkündür. Bir diğer ifade ile öğretmenlerle yapılan çalışmaların sınırlı sayıda olduğu ifade edilebilir (Sürmeli, Duru ve Duru, 2017). Özellikle nükleer santralin kurulduğu bölgede eğitimciler ile ilgili bir çalışmaya alanyazında ulaşılamamıştır. Wiyarsi ve Çalık (2019) tarafından tartışmalı konular ele alınırken veri toplanan ortamın ve bağlamın önemli olduğu belirtilmektedir. Nitekim Kılınç, Boyes ve Stanisstreet'in (2012) çalışmalarında yukarıdaki görüşü destekleyen sonuçlara ulaşılmaktadır. Söz konusu çalışmada nükleer santral ile ilgili görüşler incelendiğinde Sinop ve Mersin'de toplanan veriler benzerlik gösterirken Kırşehir'de toplanan veriler kısmen farklılık göstermektedir. Bir diğer ifade ile sosyobilimsel konularda bireyler görüş beyan ederken çevresel faktörlerden ve içinde bulunulan coğrafyadan etkilenebilirler (Tonus, 2012; Öztürk ve Leblebicioğlu, 2015). Bu bağlamda nükleer santralin kurulduğu bölgede görev yapan öğretmenlerle ilk kez böyle bir çalışma yapılmış olmasının alanyazına katkı sağlayabileceği umulmaktadır. Bununla birlikte öğretmenlerin toplumu yönlendirebilme becerisine sahip olduğu düşünülmektedir. $\mathrm{Bu}$ sebeple sosyobilimsel konulardan birisi olan nükleer enerji konusunda öğretmen görüşlerinin belirlenmesi gelecek nesillerin görüşleri hakkında önceden bilgi sağlayabileceği için önemlidir (Yener, Aksüt, Somuncu Demir, 2017). Bu düşünceden yola çıkılarak, bu araştırmada Mersin ilinin Gülnar ilçesinde bulunan fen bilimleri öğretmenlerinin nükleer enerji ve nükleer santrallerin kurulmasına yönelik görüşlerinin belirlenmesi amaçlanmıştır. 


\section{Yöntem}

Araştırma, nitel araştırma yöntemlerinden durum çalışmasına göre yürütülmüştür. Durum çalışması, güncel bir olguyu kendi gerçek yaşam çerçevesi içinde çalışan, olgu ve içinde bulunduğu içerik arasındaki sınırların kesin hatlarıyla belirgin olmadığ 1 ve birden fazla kanıt veya veri kaynağının mevcut olduğu durumlarda kullanılan bir araştırma yöntemidir (Yin, 1984). Bu çalışmanın ise Mersin ili içinde Akkuyu bölgesinde görev yapmakta olan fen bilimleri öğretmenlerinin yaşadıkları ortamda görüşlerinin alınmasından dolayı durum çalışması olduğu düşünülmektedir.

\section{Araştırmanın Çalışma Grubu}

Araştırmaya, Mersin ilinin Gülnar ilçesinde ve Akkuyu bölgesinde görev yapmakta ve mesleki deneyimi 5 ile 15 yıl arasında olan beş fen bilimleri öğretmeni gönüllü olarak katılmıştır. Araştırmada ögretmenlerin gerçek isimleri kullanılmamıştır. Katılımcıların gerçek isimleri yerine tablolarda “ $\mathrm{O}_{1}, \ddot{O}_{2}, \ddot{\mathrm{O}}_{3}, \ddot{\mathrm{O}}_{4}, \ddot{\mathrm{O}}_{5}$ "' kodları kullanılmıştır. Mersin ili Gülnar ilçesinde altı tane erkek bir tane kadın olmak üzere toplamda yedi fen bilimleri öğretmeni bulunmaktadır. Bu öğretmenlerin beş tanesi çalı̧̧maya gönüllü katılım sağlarken iki öğretmen katılım göstermemiştir.

\section{Verilerin Toplanması}

Veri toplama aracı olarak yarı yapılandırılmış görüşme kullanılmıştır. Görüşme sırasında öğretmenlerin onayı alınarak ses kayıt cihazı ile görüşmeler kayıt altına alınmıştır. Araştırmacılar nükleer santral ile ilgili dokuz soruluk bir veri toplama aracı geliştirmiştir. Soruların anlaşılabilirliği ile ilgili iki alan eğitimcisinin görüşü uzmanın görüşü olarak alınmıştır. Görüşme sorularına son şekli verilmiştir. Sorular şu şekildedir:

- Nükleer enerjiyi nasıl tanımlarsınız?

- Nükleer enerji hakkında ne düşünüyorsunuz?

- Sizce nükleer enerji hangi alanlarda kullanılır?

- Nükleer enerji ve nükleer santraller hakkında bilgi edindiğiniz kaynaklar nelerdir? (televizyon, internet, kitaplar, sempozyum, sivil toplum kuruluşları vb.)

- Size göre nükleer enerjinin yararları var mıdır? Varsa nelerdir?

- Size göre nükleer enerjinin zararları var mıdır? Varsa nelerdir?

- Size göre nükleer enerjiye alternatif enerji kaynağı ne/neler olabilir? Neden ?(su, rüzgar, doğalgaz, güneş, jeotermal, petrol vb.)

- Yaşadığınız yerde (Akkuyu'da) nükleer santral kurulmasına ilişkin duygu ve düşünceleriniz nelerdir? (duygusal, ekonomik, gelişmişlik vb. )

- Ülkemizin enerji ve tabii kaynaklar bakanı olduğunuzu varsayalım. Enerji konusunda hangi uygulamaları yaparsınız? (Bir diğer ifade ile enerji sorununu nasıl çözerdiniz?)

- Eklemek istedikleriniz var midır?

Öğretmenlere yöneltilen sorularla öğretmenlerin nükleer ile ilgili temel bilgi birikimleri belirlenmeye çalışılmıştır. Soruları cevaplama sürecinde öğretmenlere herhangi bir süre sınırı konulmamış olup görüşmeler yaklaşık olarak yirmi dakika sürmüştür.

\section{Verilerin Analizi}

Öğretmenlerden elde edilen veriler, nitel araştırma analiz yöntemlerinden içerik analizine göre analiz edilmiştir. İçerik analizi, araştırma sonucu benzerliği olan veriler belirli kavram ve tema etrafinda gruplanmaktadır. Gruplara ayrılan veriler incelenerek ve anlamlı bölümlere ayrılarak kodlamalar aracılığı ile belirlenir. Belirlenmiş olan kodların bir araya getirilmesiyle temalar oluş̧urulur (Yıldırım ve Şimşek, 2016). Bu çalışmada da öğretmenler ile yapılan görüşmeler esnasında alınan ses kayıtları ile transkriptler oluşturulmuştur. Oluşturulan transkriptler tekrar öğretmenlere sunularak onların görüşlerini belirtip belirtmediği tespit edilmiştir. Katılımcı teyidi doğrultusunda gerekli düzenlemeler yapılmıştır. Transkriptlerin analizi sonucu kategori ve alt kategoriler oluşturulmuştur. Bulgular tablolar matris ve ağ oluşturma şeklinde analiz edilmiştir. Görüşme verilerinin sunumunda ve verileri raporlaştırma aşamasında etik kurallar dikkate alınmıştır. Araştırmada geçerlik ve güvenirliği zedeleyebilecek durumları ortadan kaldırmak için araştırmacılar tarafından çeşitli önlemler alınmıştır (Yıldırım ve Şimşek, 2016). Araştırmanın geçerliğinin sağlanması için araştırmacı tarafindan hazırlanan görüşme formunun uygunluğu nitel araştırma konusunda uzman iki kişi tarafından incelenmiş ve geri bildirimde bulunulmuştur. Verilerin analizinde bir uzman ve nitel araştırma dersi 
almış yedi fen eğitimi alanında lisansüstü öğrenci ile birlikte analiz yapılmıştır. Araştırmada Miles ve Huberman'ın (1994) önerdiği güvenirlik formülü de kullanılmıştır. Tema için güvenirlik katsayısı 0,88 olarak hesaplanmıştır. Alanyazında kodlayıcılar arasındaki uyum yüzdesinin $\% 70$ veya daha fazla olması yeterli görülmektedir (Miles ve Huberman, 1994). Bu bağlamda veri analizinde güvenirliğin sağlandığı düşünülmektedir. İnandırıcılık ve aktarılabilirliğin sağlanabilmesi amacıyla öğretmen görüşlerinden kesitler alıntılar halinde bulgularda sunulmuştur.

\section{Bulgular}

$\mathrm{Bu}$ bölümde öğretmenlere sorulan sorular ve cevaplarına ilişkin bulgular ayrı başlıklar altında sunulmuştur.

\section{Nükleer enerjinin tanımı}

Öğretmenlere "Nükleer enerjiyi nasıl tanımlarsınız?" Sorusu sorularak nükleer enerji konusuna hâkim olup olmadığı incelenmiştir. Tablo 1'de öğretmenlerin cevapları sunulmuştur.

Tablo 1

Ögrretmenlerin Nükleer Enerjiyi Tanımlamaları

\begin{tabular}{llc}
\hline \multicolumn{1}{l}{ Tema } & Kod & Frekans \\
\hline \multirow{2}{*}{$\begin{array}{c}\text { Nükleer Enerji } \\
\text { Tanımı }\end{array}$} & Enerji üretimi & 5 \\
\cline { 2 - 3 } & Nötron parçacıklarının uranyum çekirdeğine gönderilmesi & 2 \\
\cline { 2 - 3 } & Radyoaktif maddelerin kullanımı & 2 \\
\hline
\end{tabular}

Cevaplar incelendiğinde tüm öğretmenler enerji üretiminden bahsetmiştir. Bununla birlikte iki ögretmenin nükleer bomba odaklı tanım yaptığı ve bir öğretmenin ise nükleer santralin gerekliliği ile ilgili bir tanım yapmış olduğu görülmektedir. Öğretmenlerin nükleer enerji kavramı ile ilgili yanıtlardan birkaç kesit sunulmuştur.

"Nötron parçacıklarının uranyum çekirdeğine gönderilmesi ile büyük bir enerji açığa çıkar bu enerjinin kullanılmasıdır. " $\ddot{O}_{5}$

"Enerji kaynağı olarak müthiş bir enerjiye sahiptir. Özellikle hayatımıza nükleer bomba ile girdi" $\ddot{O}_{3}$

\section{Nükleer enerjinin kullanım alanları}

Öğretmenlere Nükleer enerji hangi alanlarda kullanılır?" Sorusu sorulduğunda elde edilen bulgular Tablo 2'de sunulmuştur.

Tablo 2

Nükleer Enerjinin Kullanım Alanlarıyla İlgili Öğretmen Cevapları

\begin{tabular}{ccc}
\hline Tema & Kod & Frekans \\
\hline \multirow{2}{*}{\begin{tabular}{c} 
Nükleer Enerji \\
Kullanım \\
\cline { 2 - 3 } Alanı
\end{tabular}} & Elektrik ve enerji üretimi & 5 \\
\cline { 2 - 3 } & Sağlı ve tıp & 3 \\
\hline
\end{tabular}

Tablo 2 incelendiğinde öğretmenler nükleerin en fazla elektrik enerjisinin üretiminde kullanıldığını belirtmişlerdir. Tüm öğretmenler elektrik enerjisi üretimini söylerken farklı cevaplar olarak üç defa sağlık-tıp alanı, üç defa savaş-savunma alanı, iki defa uzay teknolojileri yanıtları verildiği görülmektedir. Öğretmenlerin bu konudaki görüşlerinden bir kesit aşağıda sunulmuştur;

"Hastalıkların teşhisinde yani sağllk alanında kullanılır. Savunma ve silah sanayisinde, uzay sanayisinde ve en başta elektrik üretiminde kullanılır." $\ddot{O}_{1}$

"En fazla elektrik enerjisinde kullanıliyor ya da bomba yapımında kullanıliyor." $\ddot{O}_{3}$ 


\section{Nükleer enerji ve nükleer santraller hakkında bilgi kaynakları}

Öğretmenlere "Nükleer enerji ve nükleer santraller hakkında bilgi edindiğiniz kaynaklar nelerdir?" Sorusu sorularak nükleer enerji ile ilgili edinilen bilgi kaynakları tespit edilmek istenmiştir. Elde edilen veriler Tablo 3 'te sunulmuştur.

Tablo 3

Ögretmenlerin Nükleer Enerji Hakkında Bilgi Edinme Yolları

\begin{tabular}{lcc}
\hline Tema & Kod & Frekans \\
\hline \multirow{3}{*}{$\begin{array}{c}\text { Bilgi Edinme } \\
\text { Yollar1 }\end{array}$} & Internet & 5 \\
\cline { 2 - 3 } & Sempozyum- Panel & 2 \\
\cline { 2 - 3 } & Dergi & 1 \\
\cline { 2 - 3 } & Makale & 1 \\
\cline { 2 - 3 } & Gazete & 1 \\
\hline
\end{tabular}

Verilen cevaplar incelendiğinde öğretmenlerin nükleer ile ilgili en önemli bilgi kaynağının internet olduğu görülmektedir. Bazı öğretmenler özellikle o bölgede panel, söyleşi, sempozyum gibi etkinlikler yapıldığını söylemektedir. Öğretmenlerin vermiş olduğu cevaplardan bazıları aşağıda sunulmuştur.

"Internet üzerinden bakıyorum fakat nükleer santralin yarar ve zararından ziyade tarafl yorumların olduğunu görüyorum. Olayın içeriğine bakmıyorlar." $\ddot{O}_{4}$

"Illçemizde santral yapılacağından dolayı nükleer santrali yapan şirket tarafindan (NGS) 23 Nisan, 19 Mayls gibi milli bayramlarda etkinlikleri oluyor ve geziler düzenleniyor. Bu kanallar sayesinde bilgi sahibi oluyorum. " $\ddot{O}_{2}$

\section{Nükleer enerjinin yararları ve zararları}

Öğretmenlere nükleer enerjinin yararları ve zararları sorulmuştur. Alınan cevaplar doğrultusunda Şekil 1 oluşturulmuştur.

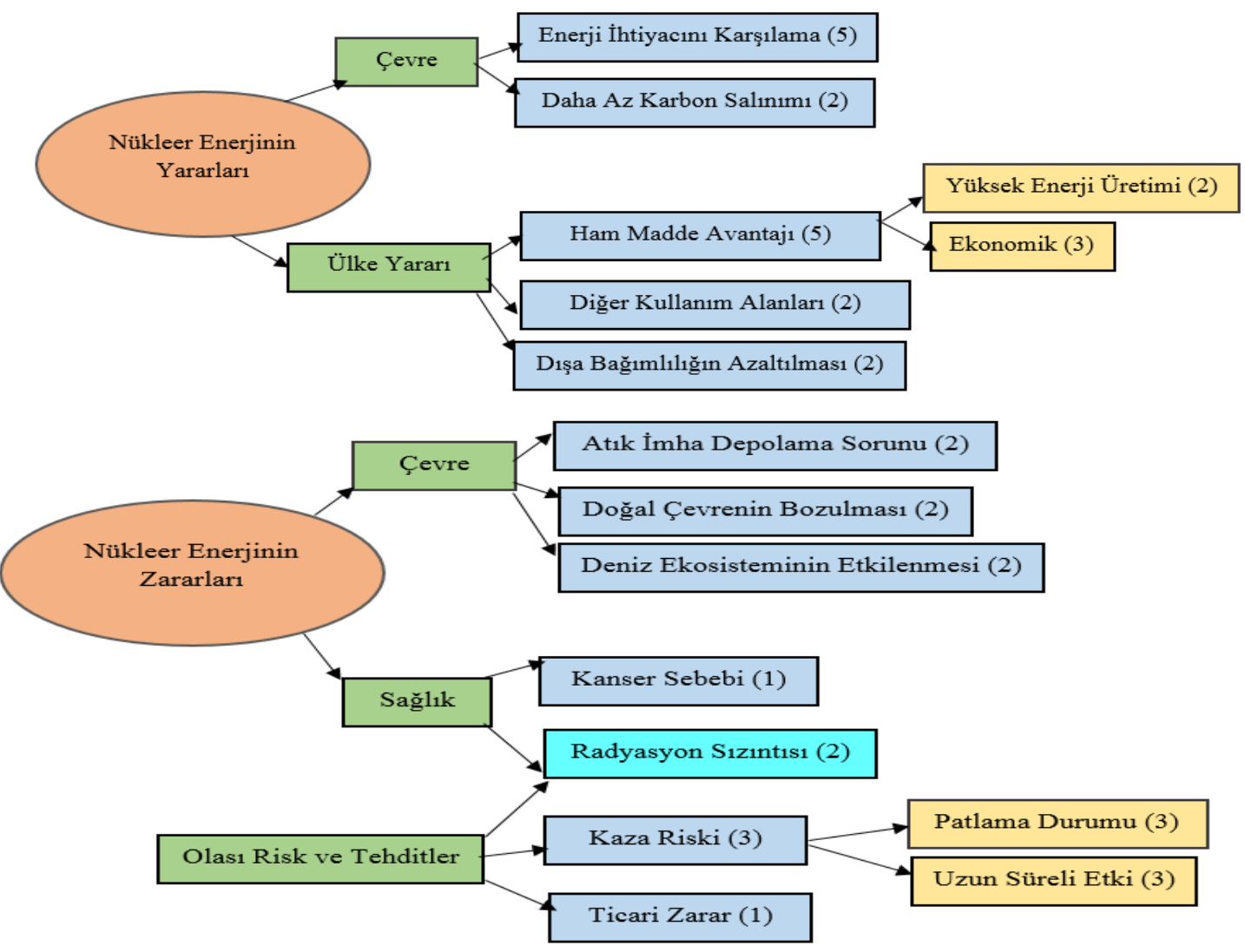

Şekil 1. Nükleer Enerjinin Yararlı ve Zararlı Yönleri 
Şekil 1'e göre öğretmenler nükleer enerjinin yararları kısmında öncelikle çevre ile ilgili kısımları dile getirmişlerdir. Öğretmenlerin tamamı enerji ihtiyacını karşılama konusuna değinirken bazı öğretmenler nükleer enerjinin daha az karbon salınımına neden olduğunu dile getirmiştir. Ayrıca ülke yararı açısından söz konusu enerjinin olumlu yönleri hammadde, savunma ve dışa bağımlılığı azaltma noktasında ayrıca ele alınmıştır. Nükleer enerjinin daha ekonomik olacağı ve hammaddenin kendi ülkemizde de fazla miktarda olduğu bu durumun bize avantaj sağlayacağı görüşündedirler. Ayrıca daha az hammadde kullanarak daha çok enerji üretimi yapıldığında enerji konusunda yüksek verim elde edilebileceği dile getirilmiştir. Bu sebeple nükleer enerjiyi kullanmanın daha ekonomik olacağı belirtilmiştir. Öğretmenlere göre nükleer enerjinin bir diğer yararı, sadece enerji konusunda değil diğer alanlarda da kullanılmasıdır. Örneğin ülke savunmasında da nükleer enerjinin olumlu etkilerinden mülakatlarda bahsedilmiştir. Yukarıdaki görüşlere ilave olarak bazı öğretmenler tarafından nükleer enerji sayesinde enerji yönünden dışa bağımlılığın azalabileceği düşünülmektedir. Yukarıda ele alınan noktalar ile ilgili bazı öğretmen görüşleri aşağıda sunulmuştur.

"Biz ülke olarak stratejik bir konumdayız. Savaş coğrafyasındaylz aslında. Bu sebeple bizim de elimizde bir güç olması gerekiyor. Ben enerjiden ziyade savunma amaçl ve elimizde bir güç bulundurma amacl ile kurulacak bu santrali önemli buluyorum." $\ddot{O}_{5}$

“Çok daha kolay enerji üretimi sağllyor ve yüksek miktarda enerji üretimi sağllyor Bu enerji üretimi

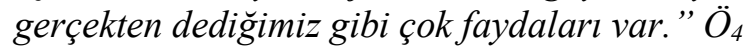

"Öncelikle dişarıya olan enerji bağımlılı̆̆ımızı azaltacaktır. Milyarlarca dolar ülkemizde kalacaktır. Petrol, doğalgaz oldukça pahalı iken uranyum o kadar da çok pahalı değil. Nükleer enerji sayesinde sera gazlarının salınımı azalacağı için hava kirliliği azalabilecektir. Küresel ısınmanın bir nebze de olsa önüne geçmiş oluruz." $\ddot{O}_{1}$

Öğretmenlerden elde edilen verilere göre nükleer enerjinin zararları üç boyutta ele alınmıştır. Çevre, sağlık, olası risk ve tehditler boyutunda veriler kategorileştirilmiştir. Çevre boyutunda öğretmenler öncelikle nükleer enerji sonucunda atıkların ve imhaların nasıl depolanacağı ya da nerede saklanacağı konusundaki belirsizliğe odaklanmışlardır. Bununla birlikte öğretmenler tarafından nükleer santralin kurulacağı bölgede deniz suyunun 1sınacağı bu doğrultuda deniz ekosisteminin bozulabileceği ve diğer canlıların da bu durumdan etkilenebileceği dile getirilmiştir. İnsanlar üzerinde de kanser etkisinin olabileceğini belirten bir öğretmen olurken radyasyon sızıntını dile getiren iki öğretmen yer almıştır. Radyasyon sızıntısı hem çevre hem de olası risk ve tehditler kategorisi ile ilişkilendirilmiştir. Görüşmelerde bazı öğretmenlerin patlama halinde oluşacak zararlardan endişe duyduğu tespit edilmiştir. Ayrıca bir öğretmen konuyu başka bir noktadan ele alarak nükleer santralin ülkemizin kendi imkânlarıyla değil de başka bir ülkenin imkânları ile kurulmasını ticari bir zarar olarak gördüğünü ifade etmiştir. Öğretmenlerin vermiş olduğu cevaplardan bazıları aşağıda kesitler halinde sunulmuştur.

"Çok daha kolay enerji üretimi sağllyor ve yüksek miktarda enerji üretimi sağllyor. Bu enerji üretimi gerçekten çok faydaları var ama zararlarını minimuma getirmek gerekiyor ve çok iyi korunması gerekiyor. " $\ddot{O}_{2}$

“... Özellikle uranyumu kullandıktan sonra atık kısımların imha edilmesi konusunda sıkıntılar olduğu ve deniz suyunun ısınacağl söyleniyor. Yani doğal çevrenin bozulacağı söyleniyor.” $\ddot{O}_{5}$

“....Günümüzdeki kanser sebeplerinin belki de birçok kısmı bu nükleer enerji patlaması (Çernobil'i kastediyor) sonucunda gerçekleşti. Bilemiyoruz." $\ddot{O}_{4}$

\section{Enerji kaynağı önerileri ve öğretmenlerin nükleer santrali destekleme/desteklememe durumları}

Öğretmenlere nükleer enerjiye alternatif olarak hangi enerjilerin kullanılabileceği ve öneriler ayrıca sorulmuştur. Ayrıca "Yaşadığınız yerde (Akkuyu'da) nükleer santral kurulmasına ilişkin duygu ve düşünceleriniz nelerdir?" ve "Ülkemizin enerji ve tabii kaynaklar bakanı olduğunuzu varsayalım. Enerji konusunda hangi uygulamaları yaparsınız?" şeklinde sorular yöneltilmiştir. Elde edilen bütün veriler Tablo 4 aracılığı ile özetlenmiştir. 
Tablo 4

Ögretmenlerin Destekleme/Desteklememe Durumlarl, Önerileri ve Alternatif Enerji Kaynă̆ Seçenekleri

\begin{tabular}{|c|c|c|c|}
\hline & Öneri & $\begin{array}{l}\text { Alternatif Enerji Kaynağı } \\
\text { Seçeneği }\end{array}$ & Destekleme Durumu \\
\hline Ö1 & $\begin{array}{c}\text { Nükleer enerji santralleri sayıca } \\
\text { arttırılmalı } \\
\text { Teşvik edilmeli }\end{array}$ & $\begin{array}{c}\text { Yenilenebilir enerji } \\
\text { kaynakları } \\
\text { (rüzgâr, güneş vb.) }\end{array}$ & + \\
\hline Ö2 & $\begin{array}{c}\text { Teşvik arttırılmalı } \\
\text { Milli üretim olmalı } \\
\text { Daha ekonomik olmalı }\end{array}$ & $\begin{array}{l}\text { Yenilenebilir enerji } \\
\text { kaynakları }\end{array}$ & $\begin{array}{c}\text { Tedirgin, endişeli } \\
-\end{array}$ \\
\hline Ö3 & $\begin{array}{c}\text { Nükleer enerji yerine rüzgâr ve güneş } \\
\text { enerjisine (yenilenebilir enerji kaynakları) } \\
\text { yönelim olmalı }\end{array}$ & $\begin{array}{l}\text { Yenilenebilir enerji } \\
\text { kaynakları }\end{array}$ & $\begin{array}{c}\text { Tedirgin, endişeli } \\
-\end{array}$ \\
\hline Ö4 & $\begin{array}{l}\text { Yenilenebilir enerjiye süreklilik } \\
\text { kazandırılmalı }\end{array}$ & $\begin{array}{l}\text { Yenilenebilir enerji } \\
\text { kaynakları }\end{array}$ & + \\
\hline 0̈5 & $\begin{array}{l}\text { Önceliğimiz yenilenebilir enerji olmalı } \\
\text { İsraf önlenmeli } \\
\text { Milli üretim olmalı } \\
\text { Ülke kendi mühendislerini yetiştirmeli } \\
\text { Kendi nükleer santrallerini kurmalı }\end{array}$ & $\begin{array}{l}\text { Yenilenebilir enerji } \\
\text { kaynakları } \\
\text { Elektroliz yöntemi } \\
\text { ile enerji üretimi }\end{array}$ & Tedirgin, endişeli \\
\hline
\end{tabular}

Öğretmenlere nükleer santral konusundaki önerileri sorulduğunda bazı öğretmenler teşviklerin arttırılması gerektiği ifade etmiştir. Bununla birlikte milli yani ülkenin kendi yapısı olan nükleer santral yapılmasını vurgulayan öğretmenler olduğu mülakatlarda görülmüştür. Aşağıda bu konu ile ilgili bir ifade sunulmuştur.

“... Neden biz yapmiyoruz da Rusya ve Japonya bizim ülkemizde yapıyor? ...” $\ddot{O}_{4}$

Gerek alternatif enerji kaynağı olarak gerekse nükleer santral konusunda öneri olarak yenilenebilir enerji kaynakları tüm öğretmenler tarafından dile getirilmiştir. Yenilenebilir enerji kaynaklarından rüzgâr, güneş vb enerji türleri zikredilirken farklı görüş olarak elektroliz yöntemiyle enerji üretilmesi seçeneği de bir öğretmen tarafından sunulmuştur. Ayrıca yenilenebilir enerjiye daha çok önem verilmesi gerektiği görüşünü tüm öğretmenler tarafından vurgulanan bir nokta olmuştur.

"Nükleere alternatif ne olabilir? Örneğin rüzgâr enerjisi, güneş panelleri vb. yenilenebilir enerji kaynaklarl aklıma geliyor." $\ddot{O}_{3}$

“Almanya'da mesela köylere devlet destekli güneş panelleri kuruluyor, insanlar hem kendi elektriklerini karşıllyor hem de devlet elektrik satabiliyor. Bizim ülkemiz daha önce bunun zorlukların çok yaşadl. Örneğin Karadeniz'de derede Almanya'dan gelen bir vatandaş kendi getirdiği tribünü dereye kurdu ve elektriğini üretiyordu. Vatandaşın dediğine göre devlet ondan vergi aliyordu işte bu insanları hem soğutuyor hem de uzak tutuyor." $\ddot{O}_{1}$

Nükleer santralin yapıldığı ilçede çalışmaya katılan beş öğretmen bulunmaktadır. Üç öğretmenin nükleer santralin kurulmasını istediği görülmüştür. İki öğretmen net bir şekilde isterken bir öğretmen tedirgin olmakla birlikte olumlu bir bakış içinde olduğunu dile getirmiştir. İki öğretmen ise nükleer santrali istemediğini dile getirmiştir. İstememe sebebini "ya sızıntı olursa" endişesi ile açıklamaktadır. Bu konuya ilişkin öğretmen görüşlerinin bir kısmı aşağıda sunulmuştur.

“..Tabi bu radyasyon konusunda bazen insanın zihninde soru işareti kallyor. Insan tedirgin oluyor çünkü etkilenen bölge bizim bölgemiz olacak. Bir sikıntı olmazsa güzel olacak.” $\ddot{O}_{2}$

“...Türkiye'de nükleer santral yapldı̆̆g anda direk patlayacak ve bütün ülkeyi ya da o bölgeyi yok edecekmiş gibi bir algı var. İnsanlarımızın birçoğunda özellikle bu bölgede yaşayanlarda bu algl çok net görülüyor. Daha iyi tanttılması gerektiğini düşünüyorum. Ben kendi açımdan olumlu görüyorum. "Ö

Tabloda yer almayan ancak mülakatlarda ortaya çıkan çarpıcı bir sonuçtan bahsedilebilir. Nükleer santral yapılacak olan Akkuyu bölgesinde bilgilendirme amaçlı nükleer santral ile ilgili sempozyum, 
konferans, seminer ve alan gezileri düzenlenmekte olup ve her yıl milli bayramlarda ilçede eğlence alanları oluşturularak bilgilendirme yapıldığı öğretmenler tarafından dile getiren bir diğer önemli bulgudur. Öğretmenlerin nükleer santrale karşı olumlu bakış açısına sahip olmasında bahsedilen durumun etkili olduğu mülakatlarda sıklıkla dile getirilmiştir. Aşağıda ilgili durum için bir öğretmenin ifadesine yer verilmiştir.

“... Illçemizde santrali kuracak olan şirketler (NGS) tarafindan bazen konferans ve sempozyum yapıllyor. 23 Nisan'da eğlence parkları oluşturuyorlar veya gezi düzenleniyor Akkuyu nükleer santraline. Bu sebeple de daha çok bilgimiz ve sempatimiz oldu bu konuda." $\ddot{O}_{5}$

\section{Tartışma, Sonuç ve Öneriler}

Nükleer enerji gündemde önemli tartışmalara yol açan sosyobilimsel konuların başında gelmektedir. İkilemli bu durum için Mersin-Akkuyu bölgesinde bulunan fen bilimleri öğretmenlerinin bölgeye yapılması planlanan nükleer santral ile ilgili görüşleri bu çalışma kapsamında incelenmiştir. Elde edilen sonuçlarda öğretmenlerin çoğunun nükleer enerji hakkında bilgi sahibi olduğu ve duruma bütüncül bakabildiği tespit edilmiştir. Bu durum sosyobilimsel konuların doğası ile ilişkilendirilebilir. Çünkü sosyobilimsel konular tek bir açıdan karar verilemeyen, bütüncül bakılması gereken ve sadece siyah ya da beyaz değil gri alanların olduğu konulardır (Tsai, 2018).

Araştırma kapsamında nükleer santraller ile ilgili görüşler tespit edilmeden önce öğretmenlerin nükleer enerji ile ilgili tanımlama ve bilgileri tespit edilmek istenmiş̧ir. Öğretmenlerin nükleer kavramının daha çok enerji odaklı tanımlayabildiği söylenebilir. Bunun yanında bazı öğretmenlerin nükleer kavramını bomba ile ilişkilendirebildiği görülmüştür. Öğretmenlerin nükleer enerji ve nükleer santral hakkında daha çok internet üzerinden bilgi sahibi olduğu söylenebilir (Tablo 3). Bununla birlikte ögretmenlerin bilgi kaynağı olarak makaleleri daha güvenilir bulduğu fakat en az bilgiyi makalelerden edindiği tespit edilmiştir. Benzer sonuçlar Ho, Leong, Looi ve Chuah'ın (2019) çalışmalarında da mevcuttur. İlgili çalışmada Güneydoğu Asya ülkelerinin çoğunda nükleer enerji konusunda insanların medya üzerinden bilgi sahibi olduğu tespit edilmiştir. Namdar ve Shen (2016) ile Kapıcı ve İlhan'ın (2016) yaptığı çalışmada da paralel sonuçlar elde edilmiştir. Benzer şekilde Atasoy (2018) hidroelektrik santraller, yeşil yol, organik çay gibi yerel sosyobilimsel konuları ele aldığı çalışmasında öğretmen adayları tarafindan televizyon, çevre ve internetin bilgi kaynağı olarak görüldüğü sonucuna ulaşmıştır. Bu durum sosyobilimsel konuların medyada sıklıkla yer almasıyla ilişkilendirilebilir (Cenk, 2019). Ancak öğretmenlere göre nükleer enerjinin kullanım alanları en fazla elektrik enerjisi üretimi daha sonra sağlık-tıp ve savaş-savunma teknolojileri olarak sıralanırken bilimsel alandan bahsedilmemiştir. Alanyazındaki bazı çalışmalarda da benzer olarak öğretmenlerin sosyobilimsel konularda yararlandığı kaynaklarda bilimselliğin ön planda yer almadığı sonucuna ulaşılmıştır (Demircioğlu ve Uçar, 2014; Genel ve Topçu, 2016; Karademir, Toroğlu ve Avc1, 2017; Kılınç, Boyes ve Stanisstreet, 2012; Kolsto 2006; Ratcliffe 1997; Ratcliffe ve Grace, 2003; Wu ve Tsai, 2007). Oysaki nükleer santraller de dâhil olmak üzere tüm sosyobilimsel konularda öğretmenlerin entelektüel düzeyde bilgi sahibi olması beklenmektedir (Sevim ve Ayvacı, 2020).

Öğretmenlerin nükleer enerji ile ilgili tanımlamaları ve bilgileri mülakatlarda yer aldıktan sonra Akkuyu bölgesinde inşası devam eden nükleer santral ile ilgili kısım üzerinde durulmuştur. Mülakatın bu bölümünde çarpıcı sonuçlara ulaşılmıştır. Beş öğretmenden oluşan çalışma grubunda üç öğretmenin yaşadığı ilçeye nükleer santral kurulmasının ve nükleer enerji kullanılmasını onayladığı ancak kısmen de olsa bir takım endişelerinin olduğu dile getirilmiştir. Benzer sonuçlar Karademir, Toroğlu ve Avcı'nın (2017) çalışmalarında da görülmüştür. İlgili çalışmada Akkuyu bölgesinde bulunan yöre halkının nükleer santral kurulması konusunda olumlu görüşlerinin olduğu ancak nükleer santralin Mersin ilinde kurulacak olması hususunda olumsuz görüşler ile birlikte kısmen endişenin de olduğu saptanmıştır. Ancak bu iki araştırmadan elde edilen bulgunun, alanyazında yer alan çalışmaların (Ansolabehere, Konisky, 2009; Burger, 2012; Ho, Oshita, Looi, Leong ve Chuah, 2019; Palabiyık, Yavaş, Aydın, 2010b) sonuçları ile farklılık gösterdiği söylenebilir. Bu farklılığın nedeni diğer çalışmalarda çoğu katılımcının nükleer santral kurulmasını onaylamadığı görülmüsştür. Bu araştırmada ise çoğunluğun onayladığı tespit edilmiştir. Onaylamayan iki kişi tarafından patlama, sızıntıya karşı gerekli tedbirler alınırsa ülkemize nükleer santralin gerekli olduğu ifade edilmiştir. Söz konusu durumun sebebi bölgede yapılan tanıtım toplantıları ve etkinliklerin etkisi ile açıklanabilir. Çünkü mülakatlarda nükleer santral bölgesine alan gezilerinin düzenlendiği ve ilgili şirket tarafindan tanıtım 
toplantılarının yapıldığı ve kaygıların azaltıldığı sıklıkla belirtilmiştir. Bu sebeple bu araştırma sonucunun alanyazındaki sonuçlardan farklı bir sonuç gösterebildiği düşünülmektedir. Bahsedilen tanıtım toplantılarında nükleer santrallerin güvenilir, temiz, daha çok enerji üretmesi ve ekonomide artış sağlayacağı düşüncesinin vurgulandığı ve bu durumun toplumda pozitif görüş sağlanmasına neden olabildiği ifade edilmiştir. Bu durum sosyobilimsel konularda veri toplanan coğrafyanın ve çevresel faktörlerin karar vermedeki etkisi ile açıklanabilir (Tonus, 2012). Alanyazındaki ilgili çalışmalarda da benzer sonuçlar elde edilmiştir (Keller, Visschers, Siegrist, 2012; Palabıyık, Yavaş, Aydın, 2010a; Sürmeli, Duru ve Duru, 2017; Venable, Pidgeon, Simkons, Henwood, Parkhill, 2009). Buna karşın bu araştırma sonuçları Kılınç ve diğerlerinin (2012) çalışması ile tezat sonuçlar ortaya koymuştur. Bahsedilen çalışmada nükleer santral kurulan şehirlerin nükleer santraller konusunda daha muhalif olduğu, nükleer santral kurulmayan şehirlerde ise daha olumlu bir tutum geliştirildiği tespit edilmiştir. Bu farklı sonuçların çalışmaya dâhil olan örneklem ile ilişkili olabileceği düşünülmüştür. $\mathrm{Bu}$ araştırmada öğretmenlerin nükleer santral konusundaki olumlu görüşleri daha fazladır. Olumlu görüşlerin çoğunlukla enerji ve ekonomi odaklı olduğu söylenebilir. Sosyobilimsel konularda ekonomi ve çevre önemli alt boyutlardandır (Wu ve Tsai, 2007). Öğretmenlerin bu eksende düşüncelerinin olması beklenen bir durumdur. Bununla birlikte öğretmenler tarafından nükleer enerjinin kurulmasıyla birlikte enerji konusunda dışa bağımlılığın azalacağı ve nükleer enerji ile birlikte gelişmiş ülkeleri de örnek alarak onların seviyesine ulaşılacağı belirtilmiştir. Araştırma sonucuna göre diğer araştırmalarla (Ateş ve Saraçoğlu, 2013; Palabıyık ve diğerleri, 2010a) benzer sonuçların elde edildiği söylenebilir. Ayrıca bulgularda nükleer enerjinin yararları ile ilgili olarak öğretmenler nükleer enerjinin faydalarını enerji elde etme, diğer enerjilere göre daha temiz olması ve güçlü bir ülke olmak için istediği görülmüştür. Ateş ve Saraçoğlu (2013) tarafından da ülkemizde enerji ihtiyacının çok fazla olduğu ve nükleer santraller sayesinde dışarıya olan bağlılığın azalacağı dile getirilmiştir. Bununla birlikte nükleer santralin gerek kurulum aşamasında gerekse işletilmesi aşamasında yerli ve milli imkânların kullanılması gerektiğini düşünen öğretmenler bu şartlar sağlandığı takdirde nükleer santralin hem daha ekonomik hem de daha güvenilir olabileceğini ifade etmişlerdir. Görüşmelerde vurgulanan bu nokta Enerji ve Tabii Kaynaklar Bakanlığı (2016) tarafından da vurgulanmıştır. Bakanlık bu konuda Mersin'de kurulan nükleer santralde yeni iş imkânlarının yaratılacağını, ilgili Rus firmasının (NGS) inşaatın en yoğun döneminde yaklaşık 10.000 kişi ile çalışacağı ifade edilmiştir. Çalışanların büyük bir kısmının Türk vatandaşları olacağı ve Türkiye'deki şirketlerin ihale imkânlarından yararlanabileceği rapor edilmiştir. Ancak işletim aşamasına tam olarak geçilmediğinden bu durumun nasıl şekilleneceği henüz görülememektedir.

Araştırmada öğretmenlerin nükleer enerjiyi istememe sebepleri; radyoaktif sızıntı olması, nükleer atıkların boşaltılması, doğal çevreye zarar vermesi, ekolojik dengenin bozulacağı düşünceleri ve nükleer bir kaza olacağında ilk olarak o ilçede yaşayanların zarar göreceği düşüncesi etkili olmuştur. Yakın dönemde ortaya çıkan Çernobil ve Fukushima kazaları olumsuz yönde endişelerini arttırdığı ifade edilmiştir (Kuchinskaya, 2011; Özdemir, 2014; Palabıyık ve diğerleri 2010b; Ramana, 2011; Wiyarsi ve Çalık, 2019). İlgili araştırmalarda nükleer enerji ile oluşan endişelerin çeşitlilik gösterdiği tespit edilmiştir. Bu endişeler nükleer santral kazaları, nükleer santrallerin riskleri, radyoaktif sızıntı, nükleer atıkların boşaltılması ile birlikte turizm, sağlı ve çevreye olan olumsuz etkileri şeklinde sıralanabilir (Ateş ve Saraçoğlu, 2013; Burger, 2012; Kapıcı ve İlhan, 2016; Keller, Visschers, Siegrist, 2012; Kılınç ve diğerleri, 2012; Yıldırım ve Örnek, 2007).

Çalışmada, öğretmenler nükleer enerji ile birlikte yenilenebilir enerji kaynaklarının da arttırılması gerektiği görüşündedirler. Alanyazında yer alan araştırmalarda ise rüzgâr enerjisi, güneş enerjisi, gelgit enerjisi, jeotermal enerjisi ve hidrojen enerjisi gibi yenilenebilir enerji kaynaklarının kullanılması gerektiği vurgulanmıştır (Bilen, Özel, Sürücü, 2013; Burger, 2012; Greenberg ve Truelove, 2011). Çalışma sonuçlarına göre bazı önerilerde bulunulabilir.

- Öğretmenlerin nükleer enerji ve nükleer santral ile edindiği bilgilerde medyanın ve internetin etkili olduğu anlaşılmıştır. Medyanın ve internetin yanlış ve yanlı bilgi aktarımına karşı doğru bilgiyi alabilmeleri için bilimsel bilgiler içeren kamu spotu ve internet kaynakları oluşturulabilir.

- Öğretmenlerin nükleer santraller hakkında daha net ve bilimsel bilgilere sahip olabilmeleri için bilimsel makalelerin ya da bilim insanlarının öğretmen veya halk ile buluşmasını 
sağlayacak ortamların (çalıştay, konferans, televizyon programı vb.) arttırılması tavsiye edilmektedir.

\section{Kaynakça}

Ansolabehere, S., \& Konisky, D. M. (2009). Public attitudes toward construction of new power plants. Public Opinion Quaterly, 73(3), 566-577.

Atabey, N. (2016). Sosyobilimsel konu temelli bir ünitenin geliştirilmesi: 7. sınıf ögrencilerinin konu alan bilgisi ve argümantasyon nitelikleri. (Yayımlanmamış Doktora Tezi). Muğla Sıtkı Koçman Üniversitesi Eğitim Bilimleri Enstitüsü, Muğla.

Atasoy, Ş. (2018). Öğretmen adaylarının yaşam alanlarına göre yerel sosyobilimsel konular ile ilgili informal muhakemeleri. Fen Bilimleri Öğretimi Dergisi, 6(1), 60-72.

Ateş, H. (2013). Fen bilgisi öğretmen adaylarının nükleer enerji hakkındaki düşünceleri. (Yayımlanmamış Yüksek Lisans Tezi). Erciyes Üniversitesi Eğitim Bilimleri Enstitüsü, Kayseri.

Ateş, H., \& Saraçoğlu, M. (2013). Fen bilgisi öğretmen adaylarının gözünden nükleer enerji. Ahi Evran Üniversitesi Kırşehir Ĕ̈itim Fakültesi Dergisi, 14(3), 175-193 .

Ayaz, E., Karakaş, H., \& Sarıkaya, R. (2016). Sınıf öğretmeni adaylarının nükleer enerji kavramına yönelik düşünceleri: bağımsız kelime ilişkilendirme örneği. Fen Bilimleri Dergisi, 37, 42-54.

Aydın, C. İ. (2020). Nuclear energy debate in Turkey: Stakeholders, policy alternatives, and governance issues. Energy Policy, 136, 1-17, DOI:10.1016/j.enpol.2019.111041

Bilen, K., Özel, M., \& Sürücü, A. (2013). Fen bilgisi öğretmen adaylarının yenilenebilir enerjiye yönelik tutumları. Dumlupınar Üniversitesi Sosyal Bilimler Dergisi, 36, 101-112.

Borgerding, L. A., \& Dagistan, M. (2018). Preservice science teachers' concerns and approaches for teaching socioscientific and controversial issues. Journal of Science Teacher Education, 29(4), 283-306, DOI:10.1080/1046560X.2018.1440860

Burger, J. (2012). Rating of worry about energy sources with respect to public health, environmental health and workers. Journal of Risk Research, 15(9), 1159-1169.

Cenk, A. G. (2019). Fen bilimleri ögretmen adaylarının sosyobilimsel konularda argümantasyon becerilerinin incelenmesi: Konu bağlamının etkisi. (Yayımlanmamış Yüksek Lisans Tezi). Mersin Üniversitesi Eğitim Bilimleri Enstitüsü, Mersin.

Dawson, V., \& Carson, K. (2017). Using climate change scenarios to assess high school students' argumentation skills. Research in Science \& Technological Education, 35(1), 116.

Demircioğlu, T., \& Uçar, S. (2014). Akkuyu nükleer santrali konusunda üretilen yazılı argümanların incelenmesi. Illkögretim Online, 13(4), 1373-1386.

Dikmenli, Y., Öztürk Demirbaş, Ç., \& Gafa, İ. (2019). Öğretim elemanlarının Türkiye'de nükleer enerjiye yönelik görüşleri. Gazi Eğitim Bilimleri Dergisi, 5, 254-272 .

Driver, R., Newton, P., \& Osborne, J. (2000). Establishing the norms of scientific argumentation in classrooms. Science Education, 84(3), 287-312.

Enerji ve Tabi Kaynaklar Bakanlığı (2014). Nükleer santraller ve ülkemizde kurulacak nükleer santrallere ilişkin bilgiler (Rapor No: 1). Ankara: Nükleer Enerji Proje Uygulama Dairesi Başkanlı̆̆l.

Enerji ve Tabii Kaynaklar Bakanlığı. (2016). Akkuyu nükleer güç santrali. Nükleer Enerji Proje Uygulama Dairesi Başkanlığı: http://nepud.enerji.gov.tr/tr-TR/Sayfalar/AkkuyuNukleer-GucSantrali adresinden alınd 1

Eş, H., Mercan, S. I., \& Ayas, C. (2016). Türkiye için yeni bir sosyo-bilimsel tartışma: nükleer ile yaşam. Turkish Journal of Education, 5(2), 47-59. 
Evren-Yapıcıoğlu, A. (2016). Fen bilimleri öğretmen adaylarının sosyobilimsel durum temelli öğretim yaklaşımı uygulama modellerine yönelik görüşleri. Hacettepe Üniversitesi Ĕ̈itim Bilimleri Enstitüsü Ĕgitim Araştırmaları Dergisi, 2(2), 132-151.

Furuncu, Y. (2016). Türkiye'nin enerji bağımlılığı ve Akkuyu nükleer enerji santrali. Cumhuriyet Üniversitesi Fen Fakültesi Fen Bilimleri Dergisi, 37, 198-207. DOI: 1017776/csj.22226.

Genel, A., \& Topçu, M. S. (2016) Turkish preservice science teachers' socioscientific issuesbased teaching practices in middle school science classrooms. Research in Science \& Technological Education, 34(1), 105-123, DOI:10.1080/02635143.2015.1124847

Greenberg, M. \& Truelove, H. B. (2011). Energy choices and risk beliefs: is it just global warming and fear of a nuclear power plant accident? Risk Analysis, 31(5), 819-831.

Herawati, D., \& Ardianto, D. (2017). Pre-Service Science Teachers Socioscientific Argumentation: A Decision Regarding Nuclear Power Plant. 2 ${ }^{\text {nd }}$ Asian Education Symposium (AES 2017), 390-394.

Ho, S. S., Leong, A. D., Looi, J., \& Chuah, A. S. F. (2019). Online, offline, or word-ofmouth? Complementary media usage patterns and credibility perceptions of nuclear energy information in Southeast Asia. Energy Research \& Social Science, 48, 46-56. DOI: 10.1016/j.erss.2018.09.012

Ho, S. S., Oshita, T., Looi, J., Leong, A. D., \& Chuah, A. S. F. (2019). Exploring public perceptions of benefits and risks, trust, and acceptance of nuclear energy in Thailand and Vietnam: A qualitative approach. Energy Policy, 127, 259-268. DOI: 10.1016/i.enpol.2018.12.011

Jewell, J., \& Ates, S. A. (2015). Introducing nuclear power in Turkey: a historic state strategy and future prospects. Energy Res. Soc. Sci. 10, 273-282. DOI: 10.1016/j. erss.2015.07.011.

Jho, H., Yoon, H. G., \& Kim, M. (2013). The relationship of science knowledge, attitude and decision making on socio-scientific 1ssues: The case study of students' debates on a nuclear power plant in Korea. Science \& Education, 23, 1131-1151.

Kapıc1, H. Ö., \& İlhan, G. O. (2016). Pre-service teachers' attitudes toward socio-scientific issues and their views about nuclear power plants. Journal of Baltic Science Education, $15(5), 642-652$.

Karademir, N., Toroğlu, E., \& Avcı, T. (2017). Nükleer enerji santrallerine halkın bakışı: Akkuyu (Mersin) örneği. Çukurova Araştırmaları Dergisi, 3(2), 150-164.

Keller, C., Visschers, V., \& Siegrist, M. (2012). Affective imagery and acceptance of replacing nuclear power plants. Risk Analysis, 32(3), 464-477.

Kılınç, A., Boyes, E., \& Stanisstreet, M. (2012). Exploring students' ideas about risks and benefits of nuclear power using risk perception theories. Journal of Education and Technology, 22(3), 252-266

Kinslow, A. T., Sadler, S. D., \& Nguyen, H. T. (2019) Socio-scientific reasoning and environmental literacy in a field-based ecology class. Environmental Education Research, 25(3), 388-410, DOI: 10.1080/13504622.2018.1442418

Kolsto S. D. (2001). 'To trust or not to trust,...'-Pupils' ways of judging information encountered in a socio-scientific issue. International Journal of Science Education, 23(9), 877-901.

Kolsto, S. D. (2006). Patterns in students' argumentation confronted with a risk focused socio scientific issue. International Journal of Science Education, 28(14), 1689-1716.

Kubota, Y. (2012). Facing a crisis with calmness? The global response to the fukushima nuclear disaster. Japanese Journal of Political Science, 13(3), 441-466. 
Kuchinskaya, O. (2011). Articulating the signs of danger: Lay experiences of post-Chernobyl radiation risks and effects. Public Understanding of Science, 20(3), 405-421. DOI: $\underline{10.1177 / 0963662509348862}$

Lee, L. S., \& Yang, H. C. (2013). Technology Teachers' Attitudes toward Nuclear Energy and Their Implications for Technology Education. Paper presented Pupils' Attitude Towards Technology (PATT). Technology Education for the Future: A Play on Sustainability Conference, New Zealand.

Miles, M. B., \& Huberman, A.M. (1994). Qualitative data analysis: An expanded Sourcebook. (2nd ed). Thousand Oaks, CA: Sage.

Namdar, B., \& Shen, J. (2016). Intersection of argumentation and the use of multiple representations in the context of socioscientific issues. International Journal of Science Education, 38(7), 1100-1132, DOI: 10.1080/09500693.2016.1183265

Nielsen, J. A. (2012). Science in discussions: an analysis of the use of science content in socio-scientific discussions. Science Education, 96(3), 428-456.

Okada, A. (2008). "Scaffolding school pupils' scientific argumentation with evidence based dialogue maps". Knowledge cartography: Software tools and mapping techniques, (Ed.) Okada, A., Buckingham Shum, S. \& Sherborne, T. (p.131-162). London: Springer.

Özdemir, N. (2014). Sosyobilimsel esaslar çerçevesinde sosyobilimsel konuları tartışmak tutumları nasıl etkiler? Nükleer Santraller. Turkish Studies, 9(2), 1197-1214.

Özdemir, N., \& Çobanoğlu, E. O. (2008). Türkiye'de nükleer santrallerin kurulması ve nükleer enerji kullanımı konusundaki öğretmen adaylarının tutumları. Hacettepe Üniversitesi Eğitim Fakültesi Dergisi, 34, 218-232.

Öztürk, S., \& Leblebicioğlu, G. (2015). Investigation of reasoning modes in making a decision about hydroelectric power plants which is a socioscientific issue. Necatibey Ĕ̈itim Fakültesi Elektronik Fen ve Matematik Ĕ̆itimi Dergisi, 9(2),1-33.

Palabıyık, H., Yavaş, H., \& Aydın, M. (2010a). Türkiye'de nükleer santral kurulabilir mi? çatışmadan uzlaşıya: Türkiye'de nükleer enerji projelerinde sosyal kabul sorunu ve halkın reddetme sendromunun araştırılması. Girişimcilik ve Kalkınma Dergisi, 5(2), 175-201.

Palabıyık, H., Yavaş, H., \& Aydın, M. (2010b). Nükleer enerji ve sosyal kabul sorunu: NIMBY sendromu üzerine kritik bir literatür incelemesi. Süleyman Demirel Üniversitesi İktisadi ve İdari Bilimler Fakültesi Dergisi, 15(1), 45-66.

Pitiporntapin, S., Yutakom, N., \& Sadler, T. D. (2016). Thai pre-service science teachers' struggles in using Socio-scientific Issues (SSIs) during practicum. Asia-Pacific Forum on Science Learning and Teaching, 17(2), 1-20.

Ramana, M. V. (2011). Nuclear power and the public. Bulletin of the Atomic Scientists, 67(4), 43-51. DOI: $10.1177 / 0096340211413358$

Ratcliffe, M. (1997): Pupil decision making about socio scientific issues within the science curriculum. International Journal of Science Education, 19(2), 167-182.

Ratcliffe, M., \& Grace M. (2003). Science education for citizenship. Open University Press, Maidenhead.

Sadler, T. D., \& Zeidler, D. L. (2005). Patterns of informal reasoning in the context of socioscientific decision making. Journal of Research in Science Teaching,42(1), 112-138.

Sadler, T. D., \& Donnelly, L. A. (2006). Socioscientific Argumentation: The Effects of Content Knowledge and Morality. International Journal of Science Education. 28(12), 1463-1488.

Saraç, E., \& Bedir, H. (2014). Sınıf öğretmenlerinin yenilenebilir enerji kaynakları ile ilgili algıları üzerine nitel bir çalışma. Kara Harp Okulu Bilim Dergisi, 24(1), 19-45.

Saunders, K. J., \& Rennie, L. J. (2013). A pedagogical model for ethical inquiry into socioscientific issues in science. Research Science Education, 43, 253-274. DOI: 10.1007/s11165-011-9248-z. 
Seçkin Karaca, H. (2018). Yapılandırmacı yaklaşım yoluyla sosyobilimsel konulara dayalı fen eğitiminin 7. sınıf ögrencileri üzerine etkileri. (Yayımlanmamış Yüksek Lisans Tezi). Trakya Üniversitesi Fen Bilimleri Enstitüsü, Edirne.

Sevim, S., \& Ayvacı, H. Ş. (2020). Öğretmen adaylarının sosyobilimsel konulardaki inançları: Nükleer enerji. Eskişehir Osmangazi Üniversitesi Türk Dünyası Uygulama ve Araştırma Merkezi Eğitim Dergisi, 5(1), 25-39.

Sürmeli, H., Duru, N., \& Duru, R. (2017). Nükleer enerji ve nükleer santraller konusuna yönelik öğretmen tutumlarının farklı değişkenler açısından incelenmesi. Necatibey Eğitim Fakültesi Elektronik Fen ve Matematik Ë̆itimi Dergisi, 11(1) , 293-319.

Temurçin, K., \& Aliağaoğlu, A. (2003). Nükleer enerji ve tartışmalar ışı̆̆ında Türkiye'de nükleer enerji gerçeği. Coğrafi Bilimler Dergisi, 1(2), 25-39.

Tsai, C. Y. (2018). The effect of online argumentation of socio-scientific issues on students' scientific competencies and sustainability attitudes. Computer \& Education, 116, 14-27.

Tonus, F. (2012). Argümantasyona dayal öğretimin ilkögretim öğrencilerinin eleştirel düşünme ve karar verme becerileri üzerine etkisi. (Yayımlanmamış Yüksek Lisans Tezi). Hacettepe Üniversitesi Eğitim Bilimleri Enstitüsü, Ankara.

Topçu, M. S. (2015). Sosyobilimsel konular ve öğretimi. (1. Bask1), Ankara: Pegem Akademi.

Udum, Ş. (2010). Turkey's nuclear comeback. The Nonproliferation Review, 17(2), 365-377.

Venable, D., Pidgeon, N., Simkons, P., Henwood, K., \& Parkhill, K. (2009). Living with nuclear power: A method study of local community perceptions. Risk Analysis, 29(8), 1090-1104.

Wiyarsi, A., \& Çalık, M. (2019). Revisiting the scientific habits of mind scale for socioscientific issues in the Indonesian context. International Journal of Science Education, 41:17, 2430-2447, DOI: 10.1080/09500693.2019.1683912

Wu, Y. T., \& Tsai, C. C. (2007). High school students' informal reasoning on a socioscientific issue: qualitative and quantitative analyses. International Journal of Science Education. 29(9), 1163-1187.

Wu, Y. T., \& Tsai, C. C. (2011). High school students' 1nformal reasoning regarding a socio scientific issue, with relation to scientific epistemological beliefs and cognitive structures. International Journal of Science Education, 33(3), 371-400.

Yapıc1, G. (2015). Nükleer enerji ve Türkiye'nin ilk nükleer santrali "Akkuyu”. Toplum ve Hekim, 30(1), 42-55.

Yener, D., Aksüt, P. \& Somuncu Demir, N. (2017). Science teacher candidates' attitudes and opinions concerning nuclear power plants: a nuclear research reactor trip. International Journal of Environmental \& Science Education, 12(5), 1283-1297.

Yıldırım, M., \& Örnek, İ. (2007). Enerjide son seçim: Nükleer enerji. Gaziantep Üniversitesi Sosyal Bilimler Dergisi, 6(1), 32-44.

Yıldırım, H., \& Şimşek, H. (2016). Sosyal bilimlerde nitel araştırma yöntemleri (10 Baskı). Ankara: Seçkin Yayıncılık.

Yılmaz, E. A. (2015). Güvenlik ve ekonomik boyutuyla nükleer enerji tartışmaları: Akkuyu nükleer santrali örneği. Cumhuriyet Üniversitesi Edebiyat Fakültesi Sosyal Bilimler Dergisi,39(1), 227-245.

Yin, R. K. (1984). Case study research: Design and methods. Beverly Hills, CA: Sage.

Zeidler, D. L., \& Nichols, B. H. (2009). Socioscientific theory and practice. issues: Journal of Elementary Science Education, 21(2), 49-58.

Zeidler, D., Walker, K., Ackett, W., \& Simmons, M. (2002). Tangled up in views: Beliefs in the nature of science and responses to socioscientific dilemmas. Science Education, 86(3), $343-367$. 
Zengin, F., Keçeci, G., \& Kırılmazkaya, G. (2012). İlköğretim öğrencilerinin nükleer enerji sosyo-bilimsel konusunu online argümantasyon yöntemi ile öğrenmesi. Education Sciences, 7(2), 647-654 .

Zohar, A., \& Nemet, F. (2002). Fostering students ${ }^{e e}$ knowledge and argumentation skills through dilemmas in human genetics. Journal of ResearSch in Science Teaching. 39, 3662. 